\title{
Prospect for immunological therapies of the equine malignant melanoma
}

\author{
Jessika-M. V. Cavalleri', Kathrin Mählmann², Hans-Joachim Schuberth ${ }^{3}$ and Karsten Feige ${ }^{7}$ \\ ${ }^{1}$ Clinic for Horses, University of Veterinary Medicine Hanover, Foundation, Hanover, Germany \\ 2 Equine Clinic, University of Berne, Vetsuisse Faculty, Berne, Switzerland \\ 3 Immunology Unit, University of Veterinary Medicine Hanover, Foundation, Hanover, Germany
}

\begin{abstract}
Summary: Although equine melanocytic neoplasms occur frequently, at least in grey horses, their existence is neglected frequently, despite their potentially severe clinical consequences. Immune-based therapies have been investigated in human metastatic melanoma and offer encouraging results. Researchers have recently begun to explore the immunological approach in equine malignant melanoma (EMM) with some success. Therefore, this review aims at giving a short overview of the nature of EMM and providing insight into the immunological basis of melanocytic neoplasms in general. Equine malignant melanoma is a true neoplasm with a genetic basis. Initially they show a slow invasive growth, but they have the potential to metastasize. EMM and human malignant melanomas share various common histopathologic features. For the immune system eradication of the tumor is a challenge. Although solid tumors are often infiltrated with immune cells, they usually do not induce a significant tumor remission. The antitumoral immune response depends on factors of the innate immune system interacting in a coordinated fashion with the adaptive immune system. Antigen-presenting cells, neutrophilic granulocytes, and lymphoid cells may elicit antitumoral effects. This innate response precedes a downstream antigen-specific response. In the tumor microenvironment of solid tumors immune suppressive factors can induce immune escape mechanisms of the tumors. Immunological therapies of EMM include blockage of histamine 2 receptors on melanoma cells and lymphocytes, cancer vaccines and gene therapeutic approaches. This article focuses on the immunological therapeutic approach of EMM and gives an outlook on future implications.
\end{abstract}

Keywords: horse, neoplasia, cancer immunity, immunotherapy, interleukin, DNA vaccine

Citation: Cavalleri J.-M. V., Mählmann K., Schuberth H.-J., Feige K. (2015) Prospect for immunological therapies of the equine malignant melanoma. Pferdeheilkunde 31, 448-460

Correspondence: Dr. Jessika-M. V. Cavalleri, Clinic for Horses, University of Veterinary Medicine Hannover, Foundation, Buenteweg 9, 30559 Hannover. E-mail: jessika.cavalleri@tiho-hannover.de

\section{Introduction}

This review describes the advances made in immune-mediated therapeutic approaches to equine malignant melanoma (EMM). After a brief outline of the nature and clinical signs of $E M M$, the main immunological principles against melanocytic neoplasms in general are depicted and therapies aiming at immune-mediated effects in the treatment of EMM are described. The review concludes with an assessment of problems encountered when attempting to establish a functional therapy and gives an outlook on future potential prospects.

Equine malignant melanoma is one of the most common neoplastic conditions of the skin in horses, with a considerably high incidence in aging grey horses (Mcfadyean 1933, Fleury et al. 2000b). It is, nowadays, accepted as a true neoplasm (Gorham and Robl 1986, Macgillivray et al. 2002, PattersonKane and Ginn 2003, Seltenhammer et al. 2004). Several research groups have investigated the genetic basis of melanoma formation and found a link between the autosomal dominant trait of greying with age and melanoma formation in horses (Rieder et al. 2000, Seltenhammer et al. 2003, Rosengren Pielberg et al. 2008, Sundstrom et al. 2012).

Typically, grey horses of five or more years are affected with EMM, showing cutaneous tumors at predilection sites, such as the ventral tail, perianal region, prepuce, eye lid, parotid, or guttural pouches (Rodriguez et al. 1998, Patterson-Kane et al. 2001, Macgillivray et al. 2002, Garvican et al. 2007). Despite their initially slow invasive growth, they frequently metastasize later (Baker and Leyland 1975, Valentine 1995, Fleury et al. 2000a, Smith et al. 2002). For further information on clinical signs and conventional therapeutic options, the reader is referred to recent extensive reviews on the matter (Metcalfe et al. 2013, Moore et al. 2013, Phillips and Lembkke 2013, Cavalleri et al. 2014).

\section{Nature of EMM}

Despite some similarities, EMM and human metastatic melanoma differ in their aetiopathology as well as in many known molecular mechanisms. The cellular origin of the neoplasm in EMM is the same as in human malignant melanomas, though. Furthermore, it is a well-accepted fact that the predominant proportion of equine melanomas progress to malignancy (Sundberg et al. 1977, Smith et al. 2002, Brown et al. 2014). Nevertheless, in contrast to human melanomas, EMM tends to show a retardation of metastasis in many cases. Similarly, the pathophysiologic role of ultraviolet (UV) light in many types of human malignant melanomas (Wood et al. 2006, Noonan et al. 2012) is of no significance in EMM, where typical predilection sites (i.e. prepuce, underside of tail and perineal region) are well protected from sunlight. Hypothetically, a mutation of the melanocortin 1 receptor (MC1R) might be involved in this difference regarding the role of UV light. Rosengren Pielberg and colleagues (2008) found an association of an increased risk of developing EMM in horses with an increase in MC1R signalling. 
It was stated that EMM could serve as an adequate animal model of naturally occurring melanomas for human dermal melanocytic disease (Tuthill et al. 1982, Heinzerling et al. 2001). Histopathologic features of EMM and human malignant melanomas were compared in a study conducted by Seltenhammer and colleagues (2004). They shared various common features identified by immunohistochemistry. In detail, melanocyte-specific proteins S-100, HMB-45 and T311 , proliferation markers PCNA and $\mathrm{Ki}-67$, and adhesion molecule CD44 stained positively in both equine and human malignant melanoma samples. Immunohistochemically and histomorphologically equine melanomas in this study proved to be comparable to particular types of human malignant melanoma, i.e. the malignant blue nevi and desmoplastic melanomas. These features add to the authors' conclusion that EMM closely resembles certain types of human malignant melanoma and, therefore, might serve as a suitable animal model of the corresponding human malignancy.

The genetic grounds in EMM development show similarities to human malignant melanoma where a family history of melanoma is one of the strongest risk factors for melanoma (Miller and Mihm 2006). However, even taking into consideration how many specific molecular mutations are known in human melanoma as opposed to how little is known in EMM, genetic predispositions likely differ substantially. There are many aspects that differ significantly from human melanoma. One unique trait of EMM seems to be the lack of junctional activity in the grey horse EMM (Fleury et al. 2000a, Seltenhammer et al. 2003). Another dissimilar characteristic is the responsibility of UV exposure for some mutations causing melanoma in humans, and a further difference between EMM and human malignant melanoma clearly is the aggressiveness of the neoplastic growth. The human melanoma is the most aggressive type of skin cancer. The median survival of patients suffering from metastatic melanoma is usually less than one year (Agarwala 2009).

Lesion site in EMM frequently corresponds to satellite and intransit lesions known in human medicine

The term satellite lesion in human malignant melanoma refers to melanoma foci in the near circumference (less than $2 \mathrm{~cm}$ ) of the primary tumor. In melanoma of the head and neck, they are encountered in approximately $3 \%$ of cases (Hasney et al. 2008). In-transit lesions, on the other hand, are tumors found at a greater distance to the primary melanoma, but still within the drainage area of the same lymph node draining the primary tumor (Hasney et al. 2008). Moore et al. (2013) proposed a clinical classification into 4 progressing stages in which horses showing only a single melanoma with a diameter $<2 \mathrm{~cm}$ and a slow growth is classified as stage 1. Stage 2 describes horses with multiple small $(<2 \mathrm{~cm})$ tumours without dissemination or metastases and a slow or quiescent growth pattern. Animals showing multiple melanomas $<4 \mathrm{~cm}$ in diameter with dissemination or metastases and a slow growth rate are classified as stage 3 . Those multiple melanomas with a diameter of $>4 \mathrm{~cm}$ and a rapid growth are classified as stage 4. The multiple tumor foci commonly observed at predilection sites accounting for stage 2 or higher normally show lesions corresponding to the human medical definition of satellite and in-transit lesions (Figure 1).
In short, the multifactorial aetiology of EMM has not yet been fully elucidated. Similarities between EMM and human disease facilitate comparisons of disease features or therapies. However, differences between the disease entities clearly exist and have to be considered.

\section{Immune mechanisms against melanocytic neoplasms}

Since neoplasms arise from the host organism's own cells, the eradication of the tumor is a challenge to the immune system. Although solid tumors are often infiltrated with a variety of immune cells, those are not usually able to induce a significant tumor remission. Recent work suggests that those T-cell inflamed tumors contain an abundant amount of immune regulatory cells and substances hindering the effective tumor lysis. Amongst these are forkhead box p3 (FoxP3) + regulatory $T$ cells (Treg), programmed death ligand 1 (PD-L1), and indoleamine-2,3-dioxygenase (IDO) inducing immune escape of tumor cells.

\section{Innate immune mechanisms}

Innate cells involved in tumor recognition and defense are antigen-presenting cell populations, neutrophils, and lymphoid cells. Macrophages and dendritic cells (DC) act as antigen presenting cells (APC) in antitumoral immune responses. DCs secrete type I interferons and present tumor derived antigens to $\mathrm{CD}^{+}{ }^{+}$T cells (Den Haan et al. 2000, Lou et al. 2007). However, depending on the microenvironment of the tumor, DC populations can be modified towards an immunosuppressive phenotype associated with tumor progression (Woo et al. 2015). Similarly, polarisation of macrophages towards a functional inflammatory phenotype (M1 macrophages) is associated with a tumoricidal activity, whereas alternatively activated M2 macrophages have a protumor phenotype and are involved in tumor growth (Sica and Mantovani 2012). Tumor associated macrophages (TAM) usually present an M2-like phenotype. Functional M1 macrophages have a high IL-12, low IL-

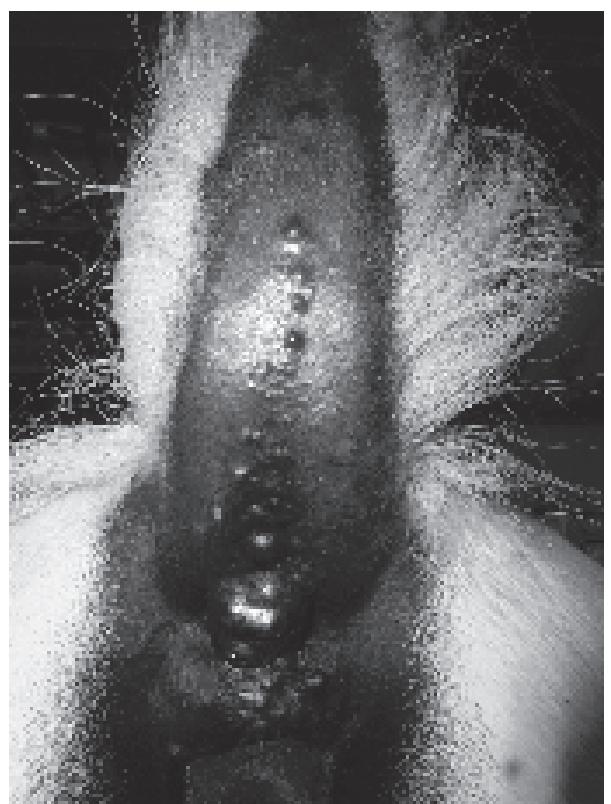

Figure 1 Dermal melanomas at a typical predilection site in the perianal region of a grey horse. 
10 cytokine profile and are activated by IFN $\gamma$ and TNF $\alpha$. M2-like TAMs have been associated with tumor progression and poor prognosis (Bingle et al. 2002, Chen et al. 2005, Zabuawala et al. 2010, Zhang et al. 2012). Cytokines and chemokines secreted by tumor cells (like CCL2, colony stimulating factor-1, IL-10 and others) can recruit monocytes and stimulate the conversion into M2-like TAMs (Hagemann et al. 2006, Qian et al. 2011 ). They result in blocking T cell proliferation and thereby inhibition of antitumoral $T$ cell responses. Immunosuppressive TAMs were shown to downregulate IL12 p70 but upregulate IL-12p40, IL-23, IL-6 and IL-10 and show a decrease in NFB and C/EBP transcription factors family members (Rodríguez et al. 2013). One proposed mechanism is the increased expression of programmed death ligand 1 (PD-L1) (Kuang et al. 2009). Blocking of the protumorigenic alternative macrophage activation in an experimental setting of murine melanoma transplants resulted in reduced melanoma outgrowth and enhancement of macrophage proinflammatory responses (Yaddanapudi et al. 2013). IFN $\gamma$ and a combination of CpG and anti-IL10-antibodies activating the TLR9 pathway have been used to switch M2-like TAMs into M1 macrophages (Guiducci et al. 2005, Duluc et al. 2009). Mirroring the M1/M2 and Th1/Th2 polarisation, neutrophils also display a plasticity resulting in antitumorigenic $\mathrm{N} 1$ and protumorigenic N2 neutrophils (Piccard et al. 2012). In investigations on infection driven stimulation of neutrophils it was shown that equine neutrophils can exhibit non-phagocytic properties and act as a crucial bridge between innate and adaptive immunity by expression of tumor necrosis factor alpha (TNF $\alpha$ ), IL-12p35, IL-12p40, IL-6, IL-8, IL-23p19 and IFN (Nerren et al. 2009). However, due to their plasticity, tumor associated neutrophils have been shown to be important in tumor development, progression and angiogenesis (Mantovani et al. 2011 ). This has also been proposed for melanoma in a mouse model (Jablonska et al. 2010).

In general, a polarisation towards M1, N1 or Th1 allows for a synergistic antitumoral immune response. Upstream of tumor-induced T cell priming type I IFNs seem to be essential for antitumor activity (Gonzalez-Navajas et al. 2012, Fuertes et al. 2013). They have been shown to activate DCs and natural killer (NK) cells and potentially inhibit infiltration of solid tumors by TAMs (Swann et al. 2007, U'ren et al. 2010). Innate lymphoid population (NK cells, NKT cell, $\gamma \delta T$ cells) are able to respond early to inflammation and may in this way be crucial in early recognition of malignant cell alterations (Woo et al. 2015). Natural killer cells have fundamental antitumoral features: They kill cells with absent or reduced MHC class I molecule expression, which is often the case during tumor progression (Davies et al. 2014). Infiltration of solid tumors with NK cells may lead to a more favourable prognosis (Pietra ef al. 2012). DNA damage of tumor cells can result from replication stress and deouble-strand helical breaks in proliferating tumor cells or tumors treated with radiation or chemotherapy. This damage can lead to a DNA damage response resulting in activation of NK cells through increased expression of NK cell-activating receptor ligands (Bartkova et al. 2005, Gorgoulis et al. 2005, Lord and Ashworth 2012, Woo et al. 2015). Various cytokines (IL-12, IL-18, IL-15, IFN $\alpha$ ) stimulate NK cell antitumoral effects by activation and maturation (Waldhaver and Steinle 2008). Antitumoral effects are mediated by perforin and granzyme release and ligands binding to Fas antigen (FasL) and the TNF-related, apoptosis-inducing ligand (TRAIL) (Cheng et al. 2013). IFN $\gamma$ secretion adds to their tumor destructive properties by enhancing the TRAIL pathway (Yang et al. 2014) and stimulates proliferation and activation of macrophages and monocytes as well as differentiation of T cell subsets (Martin-Fontecha et al. 2004). Another innate immune cell type playing a role in antitumoral immune surveillance is the Natural Killer T cell (NKT) (Smyth et al. 2000, Crowe et al. 2002). Two different forms of NKT cells are known, the CDld dependent iNKT cells and the type II NKT cells recognizing antigens on alternate $T$ cell receptors (Woo et al. 2015). Amongst antigen ligands binding on CDId is the tumor-derived disialoganglioside GD3 (Wu et al. 2003) but also CD1d-presented self-antigens on IL-12 producing DCs (Matsuda et al. 2008). Upon activation iNKT cells show cytotoxic properties and secretion of IFN $\gamma$. In contrast, type II NKT cells are described as immunoregulatory through expression of IL-13 and signal transducer and activator of transcription 6 (STAT6) in tumor models (Terabe et al. 2000, Berzofsky and Terabe 2008). The existence of an NKT/CDId system in horses has been proven (Looringh van Beeck et al. 2009). A further $\mathrm{T}$ cell subset, $\gamma \delta \mathrm{T}$ cells, is described in horses as well as in other species (Schrenzel and Ferrick 1995). Similar to NK cells they contain cytotoxic granules and are able to express/produce IFN $\gamma$, TNF $\alpha$, FasL and TRAIL (Kondo et al. 2008). They are even capable of phagocytosis (Wu et al. 2009). They are known to act as a bridge between innate and adaptive responses by various features, e.g. indirectly by activation of DCs and expressing the surface molecule CD16 and aid in antibodydependent cellular cytotoxicity (ADCC) (Tokuyama et al. 2008). However, they might also have regulatory functions in certain tumor settings (Woo et al. 2015). Interestingly, extracellular ATP release from chemotherapeutically treated tumor cells has been proposed to play an important role in activating and inducing different innate immune populations and indirectly in recruiting $\mathrm{CD}^{+}$T cells (Elliott et al. 2009, Ghiringhelli et al. 2009). Complement, a central section of the innate immunity, has been demonstrated on malignant cells and complement activation has been shown to be increased in tumor patients (Niculescu et al. 1992, Lucas et al. 1996, Rikklin et al. 2010, Ajona et al. 2013).

\section{Adaptive immune mechanisms}

The immunogenicity of melanoma antigens has been shown in several species (Speiser et al. 2003, Gyorffy et al. 2005, Wolchok et al. 2007, Yuan et al. 2009, Manley et al. 2011) and can be presumed for equine melanoma as well due to the antitumoral response seen after immune modifying therapies in EMM-bearing horses (Jeglum 1997, Heinzerling et al. 2001, Finocchiaro et al. 2009, Müller et al. 2011, Phillips and Lembcke 2013). Tumor-associated antibodies (TAA) are a central part in triggering this antitumoral response. Several TAAs known in melanoma and proposed as targets for immunotherapy are melanoma antigen recognized by $T$ cells $A$ (MART A), glycoprotein (gp) 75, gp 100, tyrosinase, melanoma antigen (MAGE), S100, MELOE-1 and -2, PNL-2 and protein gene product (PGP) 9.5 (Brichard et al. 1993, Bakker et al. 1994, Desmet et al. 1994, Gaugler et al. 1994, Kawakami et al. 1994, Brasseur et al. 1995, Wang et al. 1995, Godet et al. 2010, Ramos-Vara et al. 2014). Tyrosinase, gp100, PNL-2, PGP9.5 and S100 have been identified in EMM (Roels et al. 2000, Seltenhammer et al. 2004, Ramos- 
Vara et al. 2014). TAAs are presented to T cells either by antigen presenting cells (APC) or through major histocompatibility complexes (MHC). T cell recognition of TAA can then induce activation of effector cells, release of chemokines and cytokines and the induction of co-stimulatory molecules in order to stimulate a rather cellular Th 1 and/or predominantly humoral Th2 response (Spurrell and Lockley 2014).

In general, cytotoxic $\mathrm{CD}^{+} \mathrm{T}$ cells $(\mathrm{CTL})$ are known to have effective antitumoral properties in melanocytic neoplasms (Tuting 2013). This is presumed to be equivalent in horses. CTL generation is favoured in Th1-biased immune responses. A study on plasmid gene therapy coding for equine cytokines IL- 12 and - 18 induced an in vitro expression of IFN $\alpha$ stimulated by IL-12 (Müller et al. 2011). The apparent positive effect of intratumoral Th1 CD4+ ${ }^{+}$cells (Lowes et al. 1997, Wagner et al. 1998, Conrad et al. 1999) has yet to be proven in EMM.

Tumor infiltrating T-cells (TILs) in human melanoma may correlate positively with patient survival (Oble et al. 2009). In the case of a Th 1 response, positive effects on tumor regression were reported for tumor tissue infiltrating $\mathrm{CTL}$, T helper cells or a combination of both $\mathrm{T}$ cell populations (Topalian et al. 1989, Mihm et al. 1996, Dudley et al. 2002, Taylor et al. 2007, Hillen et al. 2008). However, infiltrating Tregs inhibit immune surveillance in the tumor microenvironment and have been associated with an increased recurrence rate in human melanoma patients (Miracco et al. 2007).
Synergism of innate and adaptive immune mechanisms in cancer surveillance and destruction

Links between innate and adaptive immunity are necessary to coordinate the immune response with innate response preceding a downstream antigen-specific response (Figure 2). One of these is IFN $\alpha$, an important cytokine for stimulation of $\mathrm{CD}^{+}{ }^{+} \mathrm{T}$ cells and NK cells (Moreno et al. 2008, Terabe and Berzofsky 2008). Furthermore, type I IFNs (mainly IFN $\alpha$ and IFN $\beta$ ) appear to be critical in bridging innate and adaptive immune responses in the tumor setting (Woo et al. 2015). Besides, cytosolic DNA-sensing pathways might contribute to innate immune sensing. Tumor-derived DNA has been detected in tumor-infiltrating DCs (Woo et al. 2014).

\section{Escape mechanisms}

Tumor cells are able to modify immune cell functions to promote tumor growth (Lacy et al. 2012). In the tumor microenvironment of solid tumors immune suppressive factors such as IDO, TGF- $\beta$, prostaglandin E2 (PGE2) and NKG2D are found (Martinet et al. 2009a, Martinet et al. 2009b). Progressing areas of human melanoma exhibited a greater number of IL10- and TGF- $\beta$-expressing $T$ cells than thinner regressive tumor areas (Conrad et al. 1999). Thus, the tumor environment tends to induce regulatory $T$ cells and inhibit antitumoral Th1 cells. Metastatic melanoma contain more Treg TILs than

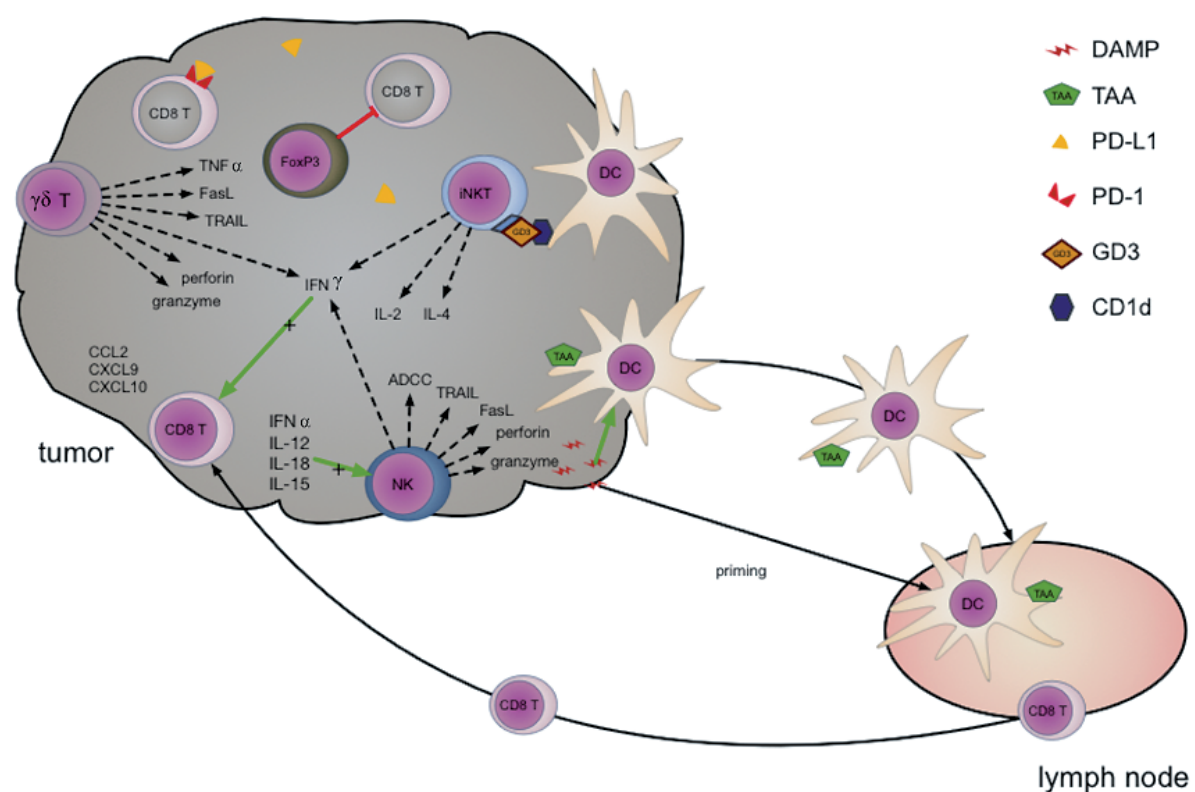

Figure 2 Line drawing of suspected immune mechanisms in solid tumors like EMM. The tumor microenvironment is abundant of antigens. Here, tumor-associated antigens (TAA) are taken up by antigen-presenting dendritic cells (DC), which after activation by damage-associated molecular patterns (DAMPs) migrate to the draining lymph node where they stimulate naive antigen-specific T-cells to become effector T cells. Primed T effector cells (here: CD8+ T-cells) traffic back to the tumor, attracted by chemokines in the tumor microenvironment like CCL2, CXCL9 and CXCL10, where they perform anti tumoral activity. In the tumor microenvironment, regulatory T cells (Tregs, FoxP3-positive) may inhibit other activated effector T cells. Similarly, tumor cells can express PD-L1 (programmed death ligand 1), an inhibitory ligand of PD- 1 (receptor expressed on activated CD8 + T-cells). Tumor-infiltrating NK cells (NK) are activated by receptors sensing tumor cell damage. This can occur spontaneously during tumor progression, by proinflammtory cytokines or in response to anti tumoral therapy. Upon activation NK cells may kill tumor cells by releasing perforin and granzyme-containing granules, expression of Fas ligand, TNF-related apoptosis-inducing ligand (TRAIL), antibody-dependent cellular cytotoxicity (ADCC) and secretion of Interferon gamma (IFN $\gamma$ ). Released TAA by lysed tumor cells are then taken up by DC. The release of Th1 - and Th2 cytokines by innate NK T-cells (iNKT) can be induced after their recognition of tumor derived disialoganglioside GD3 bound to CDId on DCs. Tumor-infiltrating gamma delta T cells $(\gamma \delta T)$ can be activated by stress induced mediators resulting in the release of perforin, granzymes as well as IFN $\alpha$, TNF $\gamma$, FasL and TRAIL. 
superficial thin melanoma lesions. Reduced immune reactions, represented by an increased expression of the regulatory $T$ cell marker FoxP3 in the primary tumor were associated with significantly decreased survival (Gerber et al. 2014).

Melanoma cells are able to express T-cell inhibitory molecules, such as programmed death-ligand 1 (PD-L1) or cytotoxic T lymphocyte antigen 4 (CTLA-4) (Jiang et al. 2013, Laurent et al. 2013). PD-L1 binds to the immune inhibitory receptor PD-1, expressed on T cells, where it inhibits the activation of antitumoral $T$ cells and stimulates Treg proliferation (Pardoll 2012). No studies regarding these inhibitory immune responses for equine melanoma have been published yet. While PD1/PD-L1 interactions play an important regulatory role in prevention of autoimmunity in infection/inflammation control, they can induce tumor immune escape and apoptosis of activated $\mathrm{T}$ cells in the tumor microenvironment. In human melanoma PD-L1 expression in tumors varies and has been associated with prognosis of response to immunotherapy targeting PD-1 or PD-L1 (Topalian et al. 2012).

\section{Immunological melanoma therapies}

Research and clinical application of immunological therapies against human malignant melanoma is extensive and, therefore, beyond the scope of this review. Hence, the reader is referred to review articles on immunological melanoma therapy for further reading (Finn 2008, Mouawad et al. 2010, Gyorki et al. 2013).

The immune reaction has to be able to overcome the inhibition induced by tumor cells in order to induce melanoma remission. This can be accomplished with therapeutics directed against tumor-specific or tumor-associated antigens (Graziano and Finn 2005). Since conventional tumor treatments like radiotherapy, chemotherapy, and photodynamic therapy have been shown to provoke apoptosis or necrosis of tumor cells, released damage-associated molecular patterns (DAMP) may enable antitumor immunity (Obeid et al. 2007, Garg et al. 2012a, Garg et al. 2012b, Dudek et al. 2013). In fact, combination therapy using conventional treatment modalities in combination with immunological therapy have been used with varying success in human melanoma patients and might therefore be interesting to try in EMM (Hoshimoto et al. 2012, Davar et al. 2013).

\section{Blockage of host molecules}

One early anti-melanoma therapy in horses targeting the immune system was the use of the histamine $2(\mathrm{H} 2)$ receptor antagonist cimetidine as an immune response stimulating agent. $\mathrm{H} 2$ receptors were demonstrated on Tregs and melanoma cells (Sahasrabudhe et al. 1987, Reynolds et al. 1996). Histamine regulates the Th1 and Th2 responses via $\mathrm{H} 1$ and $\mathrm{H} 2$ receptors on these cells (Jutel et al. 2001). Uçar (1991) demonstrated a direct effect of the $\mathrm{H} 2$ receptor antagonists cimetidine and ranitidine on murine and human melanoma cells inhibiting cell proliferation. This is an additional mechanism described to the otherwise suggested immunological effect through inhibition of Tregs (Rocklin and Haberek-Davidson 1981). Furthermore, the augmentation of natural killer cell activity against melanoma was shown for cimetidine (Flodgren et al. 1985). Goetz and colleagues described a positive therapeutic effect of cimetidine in the treatment of equine melanomas in 1990 (Goetz et al. 1990). However, in a later report, cimetidine treatment in metastatic melanoma was not successful in 5/5 horses (Macgillivray et al. 2002). Similarly, Laus and colleagues (2010) report no benefit of cimetidine monotherapy in EMM in a controlled clinical trial using two different dosing regimes (3.5 mg/kg bwt BID or $7.5 \mathrm{mg} / \mathrm{kg}$ bwt SID for 60 days) and a group size of five horses. Helle drew the same conclusion in a doctoral thesis of the University of Utrecht in 2012 (Helle 2012) in a study on 40 grey horses with melanoma, evaluating cimetidine treatment. Orally administered cimetidine has a low and variable bioavailability (Smyth et al. 1990), potentially impeding the successful therapy of melanoma in horses.

In human medicine, inhibitory proteins like PD-L 1 and CTLA4 provide targets for antitumoral therapies using monoclonal antibodies. Blockade of CTLA-4 with the monoclonal antibody ipilimumab leads to less suppression of T cells (Peggs et al. 2006) and improved survival in humans with metastatic melanoma (Hodi et al. 2010). Nivolumab, the monoclonal antibody targeting the T-cell surface molecule programmed death (PD) 1, has also been shown to be effective in the treatment of human melanoma (Brahmer et al. 2010, Brahmer et al. 2012, Hamid et al. 2013). Both antibodies were also used successfully in combination (Wolchok et al. 2013). However, clinical potential of this therapeutic strategy remains to be elucidated in EMM.

\section{Cancer vaccines and gene therapeutic approaches}

A specific immunotherapeutic approach using a whole-cell vaccine against equine melanoma was suggested as early as 1924 in a case report about the autologous vaccination against melanoma in one grey horse (Mertens 1924). Later, a case series was reported using an autologous vaccine as an irradiated whole-cell preparation injected subcutaneously over regional lymph nodes of 12 melanoma-bearing horses. Whole cell vaccination carries the chance to offer a wide range of tumor antigens to the immune system. To prepare the vaccine, surgical excision of a tumor was performed and a single cell suspension was prepared and cryopreserved by the laboratory. Vaccines were administered every other week for six vaccinations and every six weeks thereafter. Eleven out of 12 horses treated showed tumor regression over a follow-up period of up to two years (Jeglum 1997). Another study reports on three horses treated with an autologous vaccine prepared by the same laboratory in addition to systemic cimetidine treatment. Those horses received vaccinations for 12 to 36 months. All three horses eventually died from metastatic melanoma disease (Macgillivray et al. 2002).

At the University of Florida researchers investigated the immune response to disialoganglioside GD3 vaccination against melanoma in dogs (Milner et al. 2006). A similar therapeutic approach is under investigation in horses, too. However, to the authors' knowledge, no information on clinical trials of this vaccine in horses has been published yet.

A case report of a grey stallion with EMM describes the combination therapy of a local suicide gene therapy with ganci- 
clovir and a systemic autologous anti-cancer vaccine and adjuvant xenogeneic cell cytokine therapy (Finocchiaro et al. 2009). In this report, surgical excision of several, but not all, superficial melanomas was performed with infiltration of the surgical margins with a combination of lipid-complexed plasmid DNA encoding herpes simplex virus thymidine kinase (HSVtk) suicide gene and ganciclovir. The HSVtk suicide gene had previously been shown to sensitize transfected cells to ganciclovir (Finocchiaro et al. 2009). An autologous melanoma cell vaccine, produced from excised melanomas, was then subcutaneously injected together with live irradiated Chinese hamster ovary cells modified to synthesize human interleukin 2 and human GM-CSF. The vaccine was applied at weekly intervals for five weeks, followed by injections every other week up to day 105, and thereafter, every fourth week until day 245. At the times of vaccination, all but three remaining superficial melanomas were infiltrated with the suicide gene/ganciclovir combination. This treatment resulted in partial or complete tumor regression, even in the three untreated tumors. Thus, indicating a systemic rather than just local effect of the treatment. The disadvantages of autologous cell therapies are relatively high costs, need for a specialised laboratory to prepare the cell suspension and the patient specificity of the cell suspensions prepared.

Several other gene therapeutic approaches have been published for the treatment of EMM. One of the advantages of gene therapy is that it may reduce systemic toxicity while improving the specificity of effects (Schmidt-Wolf and SchmidtWolf 1996). Different approaches to cancer gene therapy include inserting suicide genes into the tumor (Finocchiaro et al. 2009), enhancing the immunogenicity of the tumor or the antitumoral activity of effector cells (Heinzerling et al. 2001, Müller et al. 2011 , Lembcke et al. 2012, Phillips and Lembkke 2013). Other strategies targeting the inhibition of neoangiogenesis, blockade of oncogene activity or insertion of wild-type tumor suppressor genes (Schmidt-Wolf and SchmidtWolf 1996) have not been reported in EMM treatment. Plasmids coding for antitumoral interleukins (Heinzerling et al. 2001, Müller et al. 2011) or DNA vectors encoding tumorassociated antigens (Lembcke et al. 2012, Mahlmann et al. 2015) have been evaluated for their use in EMM therapy.

The therapeutic application of genes coding for human IL-12 or equine IL-12 and - 18 in grey horses with EMM resulted in partial tumor regression (Heinzerling et al. 2001, Müller et al. 2011 ). In a double-blind placebo-controlled investigation of 26 grey horses bearing melanomas, interleukin-18 encoding plasmid DNA, interleukin-12 encoding plasmid DNA or empty plasmid DNA were injected intratumorally. Both treatment groups resulted in significant tumor regression in contrast to the placebo-treated control horses, in which tumor growth was noted over the treatment period (Müller et al. 2011).

Cell type-specific differentiation antigens came into the focus of research for a more specific antitumoral vaccination (Weide et al. 2008). Due to self-tolerance towards these differentiation antigens, the immunogenicity of vaccines targeting these proteins is weak. A fundamental aspect of therapeutic vaccinations against melanoma is to overcome these selftolerance mechanisms (Houghton 1994, Naftzger et al. 1996). Administration of DNA coding for xenogeneic melanocyte differentiation antigens was able to induce an immu- nological response against melanomas in several species (Overwijk et al. 1998, Weber et al. 1998, Zhou et al. 1999, Gold et al. 2003, Bergman et al. 2006, Yuan et al. 2009). It is suggested that the immune response against the foreign protein confers cross-reaction with the autologous antigen (Haupt et al. 2002, Houghton and Guevara-Patino 2004, Srinivasan and Wolchok 2004).

The melanocyte differentiation antigen tyrosinase gained attention as a potential target for therapeutic vaccination. Tyrosinase catalyses a rate-limiting step in melanin production (Hearing and Tsukamoto 1991, Yamaguchi and Hearing 2009), is expressed in all melanin-producing cells (Hearing and Tsukamoto 1991) and is constitutively expressed in equine melanoma cells (Seltenhammer et al. 2004, Phillips et al. 2012). Clinical and immunological effects of vaccination with xenogeneic tyrosinase DNA could be shown in dogs (Bergman et al. 2006, Liao et al. 2006) and humans (Wolchok et al. 2007, Tarhini et al. 2012). Consequently, the USDA granted a therapeutic human tyrosinase DNA vaccine against canine melanoma $\left(\right.$ Oncept $^{\circledR}$, Merial Ltd., Athens, GA) in 2010. This vaccine was able to induce specific antibodies and a cellular immune response in clinically healthy horses (Lembcke et al. 2012). The clinical off-label use of this vaccine has resulted in a favourable outcome in several horses making the therapeutical value in the therapy of EMM promising (Phillips and Lembcke 2013). However, using a different DNA vector, xenogeneic DNA vaccination of melanoma-bearing horses using human tyrosinase DNA or human gp 100 DNA did not show a beneficial advantage in comparison to interleukin 12 and 18 DNA therapy alone (Mählmann et al. 2015).

\section{Future outlook on immune therapy in EMM}

Several approaches have been used to apply functional immunological therapies to the equine melanoma patient. The majority of therapies to date have had limited success in clinical trials. The most successful immunological treatment for EMM seems to be the xenogeneic DNA vaccination with human tyrosinase DNA (Phillips and Lembcke 2013). However, detailed results on the clinical off-label use of this vaccine have not yet been published. The impairment of inhibitory signals is a treatment mechanism currently receiving a lot of attention in human oncodermatology (Wu et al. 2012). Inhibitory T-cell receptors lead to a diminished immune response. Consequently, the effectiveness of the antitumor immune response can be increased by blocking those receptors with specific monoclonal antibodies (Wu et al. 2012). Target molecules under investigation in human malignant melanoma include cytotoxic T-lymphocyte antigen 4 (CTLA-4), programmed death 1 (PD1), programmed death-ligand 1 (PD-L1), and B- and T-cell attenuator (BTLA) (reviewed in Pardoll 2012). The equine equivalents of those receptors have not been identified and, to this date, no antibodies targeting these inhibitory $\mathrm{T}$-cell receptors are available for the horse. This might be a fruitful field for further investigations in equine medicine.

Combined approaches targeting more than one molecule/effector cell will probably be more effective than monotherapies and should give guidance for future therapeutic strategies in EMM. A combination of local chemotherapy helping to destroy neoplastic tissue and, thereby, exposing 
tumor antigens and immune adjuvants activating effector cells might be a target of future research.

\section{List of abbreviations}

ADCC antibody-dependent cellular cytotoxicity

APC antigen presenting cells

ATP adenosine triphosphate

BID bis in die

BTLA B- and T-cell attenuator

bwt body weight

C/EBP CCAAT/enhancer binding protein

$\mathrm{CCL}$ chemokine ( $\mathrm{C}-\mathrm{C}$ motif) ligand

CD cluster of differentiation

CDId cluster of differentiation 1d

CpG Cytosine-phosphate-Guanosine

CTL cytotoxic CD8+ T cells

CTLA-4 cytotoxic T lymphocyte antigen 4

CXCL CXC chemokine ligand

DAMPs damage-associated molecular patterns

DC dendritic cell

GD3 ganglioside D3

DNA desoxyribonucleic acid

EMM equine malignant melanoma

FasL Fas antigen ligand

FoxP3 forkhead box p3

GM-CSF granulocyte monocyte colony stimulating factor

gp glycoprotein

$\mathrm{H} \quad$ histamine

HMB-45 homatropine methyle bromide-45

HSVtk herpes simplex virus thymidine kinase

IDO indoleamine-2,3-dioxygenase

IFN interferon

IL interleukin

iNKT innate NK T-cells

Ki-67 kinase inhibitor 67

MAGE melanoma antigen encoding

MART A melanoma antigen recognized by $T$ cells $A$

MC1R melanocortin type-1 receptor

MELOE melanoma-overexpressed antigen

MHC major histocompatibility complex

NF B nuclear factor kappa B

NK Natural Killer

NKG2D natural killer group 2, member D

PCNA proliferative cell nuclear antigen

PD programmed death

PD-L1 programmed death ligand 1

PGE2 prostaglandin E2

PGP protein gene product

SID semel in die

STAT6 signal transducer and activator of transcription 6

T-311 tyrosinase-311

TAA tumor-associated antigen

TAM Tumor associated macrophages

TGF-B transforming growth factor

Th Thelper

TILs Tumor infiltrating T-cells

TLR9 toll like receptor 9

TNF tumor necrosis factor

TRAIL TNF-related apoptosis-inducing ligand

Treg regulatory $T$ cell

USDA United States Department of Agriculture

UV Ultraviolet

\section{Conflict of interest statement}

None of the authors of this paper has a financial or personal relationship with other people or organisations that could inappropriately influence or bias the content of the paper.

\section{Authors' contributions}

JC designed and drafted the manuscript. KM helped to draft the manuscript. HS contributed to the conception and helped to draft the manuscript and figure. KF helped in the conception and critically revised the manuscript. All authors read and approved the final manuscript.

\section{Acknowledgements}

We thank Philip Saunders for the English editing of the manuscript.

\section{References}

Agarwala S. S. (2009) Current systemic therapy for metastatic melanoma. Expert Rev. Anticancer Ther. 9, 587-595

Ajona D., Pajares M. J., Corrales L., Perez-Gracia J. L., Agorreta J., Lozano M. D., Torre W., Massion P. P., De-Torres J. P., Jantus-Lewintre E., Camps C., Zulueta J. J., Montuenga L. M., Pio R. (2013) Investigation of complement activation product $\mathrm{C} 4 \mathrm{~d}$ as a diagnostic and prognostic biomarker for lung cancer. JNCl-. Natl. Cancer Inst. 105, 1385-1393

Baker J. R., Leyland A. (1975) Histological survey of tumours of the horse, with particular reference to those of the skin. The Veterinary record 96, 419-422

Bakker A. B. H., Schreurs M. W. J., Deboer A. J., Kawakami Y., Rosenberg S. A., Adema G. J., Figdor C. G. (1994) Melanocyte lineage-specific antigen GP100 is recognized by melanoma-derived tumor-infiltrating lymphocytes. J. Exp. Med. 179, 1005-1009

Bartkova J., Horejsi Z., Koed K., Kramer A., Tort F., Zieger K., Guldberg P., Sehested M., Nesland J. M., Lukas C., Orntoft T., Lukas J., Bartek J. (2005) DNA damage response as a candidate anti-cancer barrier in early human tumorigenesis. Nature 434, 864-870

Bergman P. J., Camps-Palau M. A., Mcknight J. A., Leibman N. F., Craft D. M., Leung C., Liao J., Riviere I., Sadelain M., Hohenhaus A. E., Gregor P., Houghton A. N., Perales M. A., Wolchok J. D. (2006) Development of a xenogeneic DNA vaccine program for canine malignant melanoma at the Animal Medical Center. Vaccine 24, 4582-4585

Berzofsky J. A., Terabe M. (2008) A novel immunoregulatory axis of NKT cell subsets regulating tumor immunity. Cancer Immunol. Immunother. 57, 1679-1683

Bingle L., Brown N. J., Lewis C. E. (2002) The role of tumour-associated macrophages in tumour progression: implications for new anticancer therapies. J. Pathol. 196, 254-265

Brahmer J. R., Drake C. G., Wollner I., Powderly J. D., Picus J., Sharfman W. H., Stankevich E., Pons A., Salay T. M., Mcmiller T. L., Gilson M. M., Wang C., Selby M., Taube J. M., Anders R., Chen L., Korman A. J., Pardoll D. M., Lowy I., Topalian S. L. (2010) Phase I study of single-agent anti-programmed death-1 (MDX-1106) in refractory solid tumors: safety, clinical activity, pharmacodynamics, and immunologic correlates. J. Clin. Oncol. 28, 3167-3175

Brahmer J. R., Tykodi S. S., Chow L. Q., Hwu W. J., Topalian S. L., Hwu P., Drake C. G., Camacho L. H., Kauh J., Odunsi K., Pitot H. C., Hamid O., Bhatia S., Martins R., Eaton K., Chen S., Salay T. M., Alaparthy S., Grosso J. F., Korman A. J., Parker S. M., Agrawal S., Goldberg S. M., Pardoll D. M., Gupta A., Wigginton J. M. (2012) Safety and activity of anti-PD-L1 antibody in patients with advanced cancer. N. Engl. J. Med. 366, 2455-2465

Brasseur F., Rimoldi D., Lienard D., Lethe B., Carrel S., Arienti F., Suter L., Vanwijck R., Bourlond A., Humblet Y., Vacca A., Conese M., Lahaye T., Degiovanni G., Deraemaecker R., Beauduin M., Sastre X., Salamon E., Dreno B., Jager E., Knuth A., Chevreau C., Suciu S., Lachapelle J. M., Pouillart P., Parmiani G., Lejeune F., Cerottini J. C., Boon T., Marchand M. (1995) Expression of magenes in primary and metastatic cutaneous melanoma. Int. J. Cancer 63, 375-380 
Brichard V., Vanpel A., Wolfel T., Wolfel C., Deplaen E., Lethe B., Coulie P., Boon T. (1993) the tyrosinase gene codes for an antigen recognized by autologeous cytolytic T-lymphocytes on HLA-A2 melanimas. J. Exp. Med. 178, 489-495

Brown E. L., Ramiya V. K., Wright C. A., Jerald M. M., Via A. D., Kuppala V. N., Hazell W. S., Lawman P. D., Lawman M. J. (2014) Treatment of Metastatic Equine Melanoma with a Plasmid DNA Vaccine Encoding Streptococcus Pyogenes EMM55 Protein. J. Equine Vet. Sci. 34, 704-708

Cavalleri J.-M. V., Maehlmann K., Steinig P., Feige K. (2014) Aetiology, clinical presentation and current treatment options of equine malignant melanoma - a review of the literature Abstracts. Pferdeheilk. 30, 455-460

Chen J. J. W., Lin Y. C., Yao P. L., Yuan A., Chen H. Y., Shun C. T., Tsai M. F, Chen C. H., Yang P. C. (2005) Tumor-associated macrophages: The double-edged sword in cancer progression. J. Clin. Oncol. 23, 953-964

Cheng M., Chen Y. Y., Xiao W. H., Sun R., Tian Z. G. (2013) NK cellbased immunotherapy for malignant diseases. Cell. Mol. Immunol. 10, 230-252

Conrad C. T., Ernst N. R., Dummer W., Brocker E. B., Becker J. C. (1999) Differential expression of transforming growth factor beta 1 and interleukin 10 in progressing and regressing areas of primary melanoma. J. Exp. Clin. Cancer Res. 18, 225-232

Crowe N. Y., Smyth M. J., Godfrey D. I. (2002) A critical role for natural killer T cells in immunosurveillance of methylcholanthreneinduced sarcomas. J. Exp. Med. 196, 119-127

Davar D., Tarhini A. A., Kirkwood J. M. (2013) Adjuvant immunotherapy of melanoma and development of new approaches using the neoadjuvant approach. Clin. Dermatol. 31, 237-250

Davies J. O., Stringaris K., Barrett J. A., Rezvani K. (2014) Opportunities and limitations of natural killer cells as adoptive therapy for malignant disease. Cytotherapy 16, 1453-1466

Den Haan J. M. M., Lehar S. M., Bevan M. J. (2000) CD8(+) but not CD8(-) dendritic cells cross-prime cytotoxic T cells in vivo. J. Exp. Med. 192, 1685-1695

Desmet C., Lurquin C., Vanderbruggen P., Deplaen E., Brasseur F., Boon T. (1994) Sequence and expression pattern of the human mage2 gene. Immunogenetics 39, 121-129

Dudek A. M., Garg A. D., Krysko D. V., De Ruysscher D., Agostinis P. (2013) Inducers of immunogenic cancer cell death. Cytokine Growth Fact. Rev. 24, 319-333

Dudley M. E., Wunderlich J. R., Robbins P. F., Yang J. C., Hwu P., Schwartzentruber D. J., Topalian S. L., Sherry R., Restifo N. P., Hubicki A. M., Robinson M. R., Raffeld M., Duray P., Seipp C. A., Rogers-Freezer L., Morton K. E., Mavroukakis S. A., White D. E., Rosenberg S. A. (2002) Cancer regression and autoimmunity in patients after clonal repopulation with antitumor lymphocytes. Science 298, 850-854

Duluc D., Corvaisier M., Blanchard S., Catala L., Descamps P., Gamelin E., Ponsoda S., Delneste Y., Hebbar M., Jeannin P. (2009) Interferon-gamma reverses the immunosuppressive and protumoral properties and prevents the generation of human tumor-associated macrophages. Int. J. Cancer 125, 367-373

Elliott M. R., Chekeni F. B., Trampont P. C., Lazarowski E. R., Kadl A., Walk S. F., Park D., Woodson R. I., Ostankovich M., Sharma P., Lysiak J. J., Harden T. K., Leitinger N., Ravichandran K. S. (2009) Nucleotides released by apoptotic cells act as a find-me signal to promote phagocytic clearance. Nature 461, 282-U165

Finn O. J. (2008) Molecular origins of cancer - Cancer immunology. N. Engl. J. Med. 358, 2704-2715

Finocchiaro L. M. E., Riveros M. D., Glikin G. C. (2009) Cytokineenhanced vaccine and suicide gene therapy as adjuvant treatments of metastatic melanoma in a horse. Vet. Rec. 164, 278-279

Fleury C., Berard F., Balme B., Thomas L. (2000a) The study of cutaneous melanomas in Camargue-type gray-skinned horses (1): clinical-pathological characterization. Pigment Cell Res. 13, 39-46

Fleury C., Berard F., Leblond A., Faure C., Ganem N., Thomas L. (2000b) The study of cutaneous melanomas in Camargue-type gray-skinned horses (2): epidemiological survey. Pigment Cell Res. 13, 47-51
Flodgren P., Malmstrom P., Axelsson B., Boketoft A., Borgstrom S., Sjogren H. O. (1985) Immune Functions in Melanoma Patients during Treatment with Interferon [Huifn-Alpha(Le] Alone or in Combination with Cimetidine. Anticancer Res. 5, 197-204

Fuertes M. B., Woo S. R., Burnett B., Fu Y. X., Gajewski T. F. (2013) Type I interferon response and innate immune sensing of cancer. Trends Immunol. 34, 67-73

Garg A. D., Krysko D. V., Vandenabeele P., Agostinis P. (2012a) The emergence of phox-ER stress induced immunogenic apoptosis. Oncoimmunol. 1, 786-788

Garg A. D., Krysko D. V., Verfaillie T., Kaczmarek A., Ferreira G. B., Marysael T., Rubio N., Firczuk M., Mathieu C., Roebroek A. J. M., Annaert W., Golab J., De Witte P., Vandenabeele P., Agostinis P. (2012b) A novel pathway combining calreticulin exposure and ATP secretion in immunogenic cancer cell death. EMBO J. 31, 10621079

Garvican E. R., Elce Y. A., Woolard K., Blikslager A. T. (2007) Preputial melanoma with systemic metastasis in a pony gelding and disseminated metastatic melanoma in a Thoroughbred gelding. Equine Vet. Educ. 19, 312-315

Gaugler B., Vandeneynde B., Vanderbruggen P., Romero P., Gaforio J. J., Deplaen E., Lethe B., Brasseur F., Boon T. (1994) Human gene mage codes for an antigene recognized on a melanoma by autologous cytolytic T-lymphocytes. J. Exp. Med. 179, 921-930

Gerber A. L., Munst A., Schlapbach C., Shafighi M., Kiermeir D., Husler R., Hunger R. E. (2014) High expression of FOXP3 in primary melanoma is associated with tumour progression. Br. J. Dermatol. 170, 103-109

Ghiringhelli F., Apetoh L., Tesniere A., Aymeric L., Ma Y. T., Ortiz C., Vermaelen K., Panaretakis T., Mignot G., Ullrich E., Perfettini J. L., Schlemmer F., Tasdemir E., Uhl M., Genin P., Civas A., Ryffel B., Kanellopoulos J., Tschopp J., Andre F., Lidereau R., Mclaughlin N. M., Haynes N. M., Smyth M. J., Kroemer G., Zitvogel L. (2009) Activation of the NLRP3 inflammasome in dendritic cells induces IL- 1 beta-dependent adaptive immunity against tumors. Nat. Med. $15,1170-\cup 1199$

Godet Y., Desfrancois J., Vignard V., Schadendorf D., Khammari A., Dreno B., Jotereau F., Labarriere N. (2010) Frequent occurrence of high affinity $T$ cells against MELOE-1 makes this antigen an attractive target for melanoma immunotherapy. Eur. J. Immunol. 40, 1786-1794

Goetz T. E., Ogilvie G. K., Keegan K. G., Johnson P. J. (1990) Cimetidine for treatment of melanomas in three horses. J. Am. Vet. Med. Assoc. 196, 449-452

Gold J. S., Ferrone C. R., Guevara-Patino J. A., Hawkins W. G., Dyall R., Engelhorn M. E., Wolchok J. D., Lewis J. J., Houghton A. N. (2003) A single heteroclitic epitope determines cancer immunity after xenogeneic DNA immunization against a tumor differentiation antigen. J. Immunol. 170, 5188-5194

Gonzalez-Navajas J. M., Lee J., David M., Raz E. (2012) Immunomodulatory functions of type I interferons. Nature Reviews Immunology 12, 125-135

Gorgoulis V. G., Vassiliou L. V. F., Karakaidos P., Zacharatos P., Kotsinas A., Liloglou T., Venere M., Ditullio R. A., Kastrinakis N. G., Levy B., Kletsas D., Yoneta A., Herlyn M., Kittas C., Halazonetis T. D. (2005) Activation of the DNA damage checkpoint and genomic instability in human precancerous lesions. Nature 434, 907-913

Gorham S., Robl M. (1986) Melanoma in the Gray Horse - the Darker Side of Equine Aging. Vet. Med. 81, 446-448

Graziano D., Finn O. (2005). Tumor Antigens and Tumor Antigen Discovery. Tumor Immunology and Cancer Vaccines. S. Khleif, Springer US. 123, 89-111

Guiducci C., Vicari A. P., Sangaletti S., Trinchieri G., Colombo M. P. (2005) Redirecting in vivo elicited tumor infiltrating macrophages and dendritic cells towards tumor rejection. Cancer Res. 65, 3437-3446

Gyorffy S., Rodriguez-Lecompte J. C., Woods J. P., Foley R., Kruth S., Liaw P. C., Gauldie J. (2005) Bone marrow-derived dendritic cell vaccination of dogs with naturally occurring melanoma by using human gp100 antigen. J. Vet. Intern. Med. 19, 56-63 
Gyorki D. E., Callahan M., Wolchok J. D., Ariyan C. E. (2013) The delicate balance of melanoma immunotherapy. Clin. Trans. Immunol. 2, e5

Hagemann T., Wilson J., Burke F., Kulbe H., Li N. F. F., Pluddemann A., Charles K., Gordon S., Balkwill F. R. (2006) Ovarian cancer cells polarize macrophages toward a tumor-associated phenotype. J. Immunol. 176, 5023-5032

Hamid O., Robert C., Daud A., Hodi F. S., Hwu W. J., Kefford R., Wolchok J. D., Hersey P., Joseph R. W., Weber J. S., Dronca R., Gangadhar T. C., Patnaik A., Zarour H., Joshua A. M., Gergich K., Elassaiss-Schaap J., Algazi A., Mateus C., Boasberg P., Tumeh P. C., Chmielowski B., Ebbinghaus S. W., Li X. N., Kang S. P., Ribas A. (2013) Safety and tumor responses with lambrolizumab (antiPD-1) in melanoma. N. Engl. J. Med. 369, 134-144

Hasney C., Butcher R. B., 2nd, Amedee R. G. (2008) Malignant melanoma of the head and neck: a brief review of pathophysiology, current staging, and management. Ochsner J. 8, 181-185

Haupt K., Roggendorf M., Mann K. (2002) The potential of DNA vaccination against tumor-associated antigens for antitumor therapy. Exp. Biol. Med. (Maywood) 227, 227-237

Hearing V. J., Tsukamoto K. (1991) Enzymatic control of pigmentation in mammals. Faseb. J. 5, 2902-2909

Heinzerling L. M., Feige K., Rieder S., Akens M. K., Dummer R. Stranzinger G., Moelling K. (2001) Tumor regression induced by intratumoral injection of DNA coding for human interleukin 12 into melanoma metastases in gray horses. J. Molecul. Med. 78, 692-702

Helle N. M. (2012). Effectiveness of cimetidine on the size of melanomas of 40 grey horses. Diss. Med. Vet. Utrecht

Hillen F., Baeten C. I., Van De Winkel A., Creytens D., Van Der Schaft D. W., Winnepenninckx V., Griffioen A. W. (2008) Leukocyte infiltration and tumor cell plasticity are parameters of aggressiveness in primary cutaneous melanoma. Cancer Immunol. Immunother. 57, 97-106

Hodi F. S., O'day S. J., Mcdermott D. F., Weber R. W., Sosman J. A. Haanen J. B., Gonzalez R., Robert C., Schadendorf D., Hassel J. C., Akerley W., Van Den Eertwegh A. J., Lutzky J., Lorigan P., Vaubel J. M., Linette G. P., Hogg D., Ottensmeier C. H., Lebbe C., Peschel C., Quirt I., Clark J. I., Wolchok J. D., Weber J. S., Tian J., Yellin M. J., Nichol G. M., Hoos A., Urba W. J. (2010) Improved survival with ipilimumab in patients with metastatic melanoma. $\mathrm{N}$. Engl. J. Med. 363, 711-723

Hoshimoto S., Faries M. B., Morton D. L., Shingai T., Kuo C., Wang H.-J., Elashoff R., Mozzillo N., Kelley M. C., Thompson J. F. (2012) Assessment of prognostic circulating tumor cells in a phase III trial of adjuvant immunotherapy after complete resection of stage IV melanoma. Ann. Surg. 255, 357

Houghton A. N. (1994) Cancer antigens: immune recognition of self and altered self. J. Exp. Med. 180, 1-4

Houghton A. N., Guevara-Patino J. A. (2004) Immune recognition of self in immunity against cancer. J. Clin. Invest. 1 14, 468-471

Jablonska J., Leschner S., Westphal K., Lienenklaus S., Weiss S. (2010) Neutrophils responsive to endogenous IFN- $\beta$ regulate tumor angiogenesis and growth in a mouse tumor model. The Journal of Clinical Investigation 120, 1151-1164

Jeglum K. A. (1997). Melanomas. Current Therapy in equine Medicine. N. E. Robinson. Philadelphia, Pennsylvania, W.B. Saunders Company, 399-400

Jiang X., Zhou J., Giobbie-Hurder A., Wargo J., Hodi F. S. (2013) The Activation of MAPK in Melanoma Cells Resistant to BRAF Inhibition Promotes PD-L1 Expression That Is Reversible by MEK and PI3K Inhibition. Clin. Cancer Res. 19, 598-609

Jutel M., Watanabe T., Klunker S., Akdis M., Thomet O. A., Malolepszy J., Zak-Nejmark T., Koga R., Kobayashi T., Blaser K., Akdis C. A. (2001) Histamine regulates T-cell and antibody responses by differential expression of $\mathrm{H} 1$ and $\mathrm{H} 2$ receptors. Nature 413, 420-425

Kawakami Y., Eliyahu S., Delgado C. H., Robbins P. F., Sakaguchi K., Appella E., Yannelli J. R., Adema G. J., Miki T., Rosenberg S. A. (1994) Identification of a human-melanoma antigen recignized by tumor-infiltrating lymphocytes associated with in vivo tumor rejection. Proc. Nat. Acad. Sci. U. S. Am. 91, 6458-6462
Kondo M., Sakuta K., Noguchi A., Ariyoshi N., Sato K., Sato S., Sato K., Hosoi A., Nakajima J., Yoshida Y., Shiraishi K., Nakagawa K., Kakimi K. (2008) Zoledronate facilitates large-scale ex vivo expansion of functional gamma delta $T$ cells from cancer patients for use in adoptive immunotherapy. Cytotherapy 10, 842-856

Kuang D. M., Zhao Q. Y., Peng C., Xu J., Zhang J. P., Wu C. Y., Zheng L. M. (2009) Activated monocytes in peritumoral stroma of hepatocellular carcinoma foster immune privilege and disease progression through PD-L1. J. Exp. Med. 206, 1327-1337

Lacy K. E., Karagiannis S. N., Nestle F. O. (2012) Immunotherapy for melanoma. Expert Rev. Dermatol. 7, 51-68

Laurent S., Queirolo P., Boero S., Salvi S., Piccioli P., Boccardo S., Minghelli S., Morabito A., Fontana V., Pietra G., Carrega P., Ferrari N., Tosetti F., Chang L. J., Mingari M. C., Ferlazzo G., Poggi A., Pistillo M. P. (2013) The engagement of CTLA-4 on primary melanoma cell lines induces antibody-dependent cellular cytotoxicity and TNF-alpha production. J. Transl. Med. 11, 108

Laus F., Cerquetella M., Paggi E., Ippedico G., Argentieri M., Castellano G., Spaterna A., Tesei B. (2010) Evaluation of cimetidine as a therapy for dermal melanomatosis in grey horse. Israel. J. Vet. Med. 65, 48-52

Lembcke L. M., Kania S. A., Blackford J. T., Trent D. J., Odoi A., Grosenbaugh D. A., Fraser D. G., Leard T., Phillips J. C. (2012) Development of Immunologic Assays to Measure Response in Horses Vaccinated with Xenogeneic Plasmid DNA Encoding Human Tyrosinase. J. Equine Vet. Science 32, 607-615

Liao J. C., Gregor P., Wolchok J. D., Orlandi F., Craft D., Leung C., Houghton A. N., Bergman P. J. (2006) Vaccination with human tyrosinase DNA induces antibody responses in dogs with advanced melanoma. Cancer Immun. 6, 8

Looringh Van Beeck F. A., Reinink P., Hermsen R., Zajonc D. M., Laven M. J., Fun A., Troskie M., Schoemaker N. J., Morar D., Lenstra J. A., Vervelde L., Rutten V. P. M. G., Van Eden W., Van Rhijn I. (2009) Functional CD1d and/or NKT cell invariant chain transcript in horse, pig, African elephant and guinea pig, but not in ruminants. Mol. Immunol. 46, 1424-1431

Lord C. J., Ashworth A. (2012) The DNA damage response and cancer therapy. Nature 481, 287-294

Lou Y. Y., Liu C. W., Kim G. J., Liu Y. J., Hwu P., Wang G. (2007) Plasmacytoid dendritic cells synergize with myeloid dendritic cells in the induction of antigen-specific antitumor immune responses. J. Immunol. 178, 1534-1541

Lowes M. A., Bishop G. A., Crotty K., Barnetson R. S., Halliday G. M. (1997) T helper 1 cytokine mRNA is increased in spontaneously regressing primary melanomas. J. Invest. Dermatol. 108, 914 919

Lucas S. D., Karlssonparra A., Nilsson B., Grimelius L., Akerstrom G., Rastad J., Juhlin C. (1996) Tumor-specific deposition of immunoglobulin $G$ and complement in papillary thyroid carcinoma. Hum. Pathol. 27, 1329-1335

Macgillivray K. C., Sweeney R. W., Del Piero F. (2002) Metastatic melanoma in horses. J. Vet. Intern. Med. 16, 452-456

Mahlmann K., Feige K., Juhls C., Endmann A., Schuberth H. J., Oswald D., Hellige M., Doherr M., Cavalleri J. M. (2015) Local and systemic effect of transfection-reagent formulated DNA vectors on equine melanoma. BMC Vet. Res. 11, 107

Manley C. A., Leibman N. F., Wolchok J. D., Riviere I. C., Bartido S., Craft D. M., Bergman P. J. (2011) Xenogeneic murine tyrosinase DNA vaccine for malignant melanoma of the digit of dogs. J. Vet. Intern. Med. 25, 94-99

Mantovani A., Cassatella M. A., Costantini C., Jaillon S. (2011) Neutrophils in the activation and regulation of innate and adaptive immunity. Nat. Rev. Immunol. 11, 519-531

Martin-Fontecha A., Thomsen L. L., Brett S., Gerard C., Lipp M., Lanzavecchia A., Sallusto F. (2004) Induced recruitment of NK cells to lymph nodes provides IFN-gamma for $\mathrm{T}(\mathrm{H}) 1$ priming. Nat. Immunol. 5, 1260-1265

Martinet L., Fleury-Cappellesso S., Gadelorge M., Dietrich G., Bourin P., Fournie J. J., Poupot R. (2009a) A regulatory cross-talk between $\mathrm{V}$ gamma $9 \mathrm{~V}$ delta $2 \mathrm{~T}$ lymphocytes and mesenchymal stem cells. Eur. J Immunol. 39, 752-762 
Martinet L., Poupot R., Fournie J. J. (2009b) Pitfalls on the roadmap to gamma delta $T$ cell-based cancer immunotherapies. Immunol. Lett. 124, 1-8

Matsuda J. L., Mallevaey T., Scott-Browne J., Gapin L. (2008) CD1drestricted iNKT cells, the 'Swiss-Army knife' of the immune system. Curr. Opin. Immunol. 20, 358-368

Mcfadyean J. (1933) Equine melanomatosis. Comp. Pathol. Therap. 46, 186-IN188

Mertens V. E. (1924) aktive Immunisierung gegen ein sarkom (Melanom eines Schimmelpferdes.). Deutsche Zeitschrift f. Chirurgie $187,216-245$

Metcalfe L. V., O'brien P. J., Papakonstantinou S., Cahalan S. D., Mcallister H., Duggan V. E. (2013) Malignant melanoma in a grey horse: case presentation and review of equine melanoma treatment options. Ir. Vet. J. 66, 22

Mihm M. C., Jr., Clemente C. G., Cascinelli N. (1996) Tumor infiltrating lymphocytes in lymph node melanoma metastases: a histopathologic prognostic indicator and an expression of local immune response. Lab. Invest. 74, 43-47

Miller A. J., Mihm M. C. Jr. (2006) Melanoma. N Engl J. Med. 355, $51-65$

Milner R. J., Salute M., Crawford C., Abbot J. R., Farese J. (2006) The immune response to disialoganglioside GD3 vaccination in normal dogs: a melanoma surface antigen vaccine. Vet. Immunol. Immunopathol. 114, 273-284

Miracco C., Mourmouras V., Biagioli M., Rubegni P., Mannucci S., Monciatti I., Cosci E., Tosi P., Luzi P. (2007) Utility of tumour-infiltrating CD25+FOXP3 + regulatory T cell evaluation in predicting local recurrence in vertical growth phase cutaneous melanoma. Oncol. Rep. 18, $1115-1122$

Moore J. S., Shaw C., Shaw E., Buechner-Maxwell V., Scarratt W. K., Crisman M., Furr M., Robertson J. (2013) Melanoma in horses: Current perspectives. Equine Vet. Educ. 25, 144-151

Moreno M., Molling J. W., Von Mensdorff-Pouilly S., Verheijen R. H. M., Hooijberg E., Kramer D., Reurs A. W., Van Den Eertwegh A. J. M., Von Blomberg B. M. E., Scheper R. J., Bontkes H. J. (2008) IFN-gamma-Producing human invariant NKT cells promote tumorassociated antigen-specific cytotoxic T cell responses. J. Immunol. 181, 2446-2454

Mouawad R., Sebert M., Michels J., Bloch J., Spano J.-P., Khayat D. (2010) Treatment for metastatic malignant melanoma: Old drugs and new strategies. Crit. Rev. Oncol. Hematol. 74, 27-39

Müller J. M. V., Feige K., Wunderlin P., Hodl A., Meli M. L., Seltenhammer M., Grest P., Nicolson L., Schelling C., Heinzerling L. M. (2011) Double-blind placebo-controlled study with interleukin-18 and interleukin-12-encoding plasmid DNA shows antitumor effect in metastatic melanoma in gray horses. J. Immunother. 34, 58-64

Naftzger C., Takechi Y., Kohda H., Hara I., Vijayasaradhi S., Houghton A. N. (1996) Immune response to a differentiation antigen induced by altered antigen: a study of tumor rejection and autoimmunity. Proc. Nat. Acad. Sci. U. S. Am. 93, 14809-14814

Nerren J. R., Payne S., Halbert N. D., Martens R. J., Cohen N. D. (2009) Cytokine expression by neutrophils of adult horses stimulated with virulent and avirulent Rhodococcus equi in vitro. Vet. Immunol. Immunopathol. 127, 135-143

Niculescu F., Rus H. G., Retegan M., Vlaicu R. (1992) Persistent complement activation on tumor cells in breast-cancer. Am. J. Pathol. 140, 1039-1043

Noonan F. P., Zaidi M. R., Wolnicka-Glubisz A., Anver M. R., Bahn J., Wielgus A., Cadet J., Douki T., Mouret S., Tucker M. A. (2012) Melanoma induction by ultraviolet $A$ but not ultraviolet $B$ radiation requires melanin pigment. Nat. Commun. 3, 884

Obeid M., Tesniere A., Ghiringhelli F., Fimia G. M., Apetoh L., Perfettini J. L., Castedo M., Mignot G., Panaretakis T., Casares N., Metivier D., Larochette N., Van Endert P., Ciccosanti F., Piacentini M., Zitvogel L., Kroemer G. (2007) Calreticulin exposure dictates the immunogenicity of cancer cell death. Nat. Med. 13, 54-61

Oble D. A., Loewe R., Yu P., Mihm M. C. Jr. (2009) Focus on TILs: prognostic significance of tumor infiltrating lymphocytes in human melanoma. Cancer Immun. 9, 3
Overwijk W. W., Tsung A., Irvine K. R., Parkhurst M. R., Goletz T. J., Tsung K., Carroll M. W., Liu C., Moss B., Rosenberg S. A., Restifo N. P. (1998) gp 100/pmel 17 is a murine tumor rejection antigen: induction of "self"-reactive, tumoricidal T cells using high-affinity, altered peptide ligand. J. Exp. Med. 188, 277-286

Pardoll D. M. (2012) The blockade of immune checkpoints in cancer immunotherapy. Nat. Rev. Cancer 12, 252-264

Patterson-Kane J. C., Ginn P. E. (2003) Dermal malignant melanoma in a horse with multifocal pancytokeratin expression. J. Vet. Diagn. Invest. 15, 54-56

Patterson-Kane J. C., Sanchez L. C., Uhl E. W., Edens L. M. (2001) Disseminated metastatic intramedullary melanoma in an aged grey horse. J. Comp. Pathol. 125, 204-207

Peggs K. S., Quezada S. A., Korman A. J., Allison J. P. (2006) Principles and use of anti-CTLA4 antibody in human cancer immunotherapy. Curr. Opin. Immunol. 18, 206-213

Phillips J. C., Lembcke L. M. (2013) Equine Melanocytic Tumors. Vet. Clin. North Am. Equine Pract. 29, 673-687

Phillips J. C., Lembcke L. M., Noltenius C. E., Newman S. J., Blakkford J. T., Grosenbaugh D. A., Leard A. T. (2012) Evaluation of tyrosinase expression in canine and equine melanocytic tumors. Am. J. Vet. Res. 73, 272-278

Piccard H., Muschel R. J., Opdenakker G. (2012) On the dual roles and polarized phenotypes of neutrophils in tumor development and progression. Crit. Rev. Oncol. Hematol. 82, 296-309

Pietra G., Manzini C., Rivara S., Vitale M., Cantoni C., Petretto A., Balsamo M., Conte R., Benelli R., Minghelli S., Solari N., Gualco M., Queirolo P., Moretta L., Mingari M. C. (2012) Melanoma cells inhibit natural killer cell function by modulating the expression of activating receptors and cytolytic activity. Cancer Res. 72, 1407 1415

Qian B. Z., Li J. F., Zhang H., Kitamura T., Zhang J. H., Campion L. R., Kaiser E. A., Snyder L. A., Pollard J. W. (2011) CCL2 recruits inflammatory monocytes to facilitate breast-tumour metastasis. Nature 475, 222-U129

Ramos-Vara J. A., Frank C. B., Dusold D., Miller M. A. (2014) Immunohistochemical Expression of Melanocytic Antigen PNL2, Melan A, S100, and PGP 9.5 in Equine Melanocytic Neoplasms. Vet. Pathol. 51, 161-166

Reynolds J. L., Akhter J., Morris D. L. (1996) In vitro effect of histamine and histamine $\mathrm{H} 1$ and $\mathrm{H} 2$ receptor antagonists on cellular proliferation of human malignant melanoma cell lines. Melanoma Res. 6, 95-99

Ricklin D., Haiishengallis G., Yang K., Lambris J. D. (2010) Complement: a key system for immune surveillance and homeostasis. Nat. Immunol. 1 1, 785-797

Rieder S., Stricker C., Joerg H., Dummer R., Stranzinger G. (2000) A comparative genetic approach for the investigation of ageing grey horse melanoma. J. Anim. Breed Genet. 117, 73-82

Rocklin R. E., Haberek-Davidson A. (1981) Histamine activates suppressor cells in vitro using a coculture technique. J. Clin. Immunol. $1,73-79$

Rodríguez D., Silvera R., Carrio R., Nadii M., Caso R., Rodríguez G., Iragavarapu-Charyulu V., Torroella-Kouri M. (2013) Tumor microenvironment profoundly modifies functional status of macrophages: Peritoneal and tumor-associated macrophages are two very different subpopulations. Cell. Immunol. 283, 51-60

Rodriguez F., Forga J., Herraez P., Andrada M., Fernandez A. (1998) Metastatic melanoma causing spinal cord compression in a horse. Vet. Rec. 142, 248-249

Roels S., Tilmant K., Van Daele A., Van Marck E., Ducatelle R. (2000) Proliferation, DNA ploidy, p53 overexpression and nuclear DNA fragmentation in six equine melanocytic tumours. J. Vet. Med. A Physiol. Pathol .Clin. Med. 47, 439-448

Rosengren Pielberg G., Golovko A., Sundstrom E., Curik I., Lennartsson J., Seltenhammer M. H., Druml T., Binns M., Fitzsimmons C., Lindgren G., Sandberg K., Baumung R., Vetterlein M., Stromberg S., Grabherr M., Wade C., Lindblad-Toh K., Ponten F., Heldin C. H., Solkner J., Andersson L. (2008) A cis-acting regulatory mutation causes premature hair graying and susceptibility to melanoma in the horse. Nat. Genet. 40, 1004-1009 
Sahasrabudhe D. M., Mccune C. S., O'donnell R. W., Henshaw E. C. (1987) Inhibition of suppressor T lymphocytes (Ts) by cimetidine. J. Immunol. 138, 2760-2763

Schmidt-Wolf G. D., Schmidt-Wolf I. G. (1996) Cancer and gene therapy. Ann. Hematol. 73, 207-218

Schrenzel M. D., Ferrick D. A. (1995) Horse (Equus-acallus) receptor Alpha-Chain, Gamma-Chain, and Delta-Chain gens - Nucleotide and tissue-specific gene-expression. Immunogenetics 42, 112-122

Seltenhammer M. H., Heere-Ress E., Brandt S., Druml T., Jansen B., Pehamberger H., Niebaver G. W. (2004) Comparative histopathology of grey-horse-melanoma and human malignant melanoma. Pigment Cell Res. 17, 674-681

Seltenhammer M. H., Simhofer H., Scherzer S., Zechner R., Curik I., Solkner J., Brandt S. M., Jansen B., Pehamberger H., Eisenmenger E. (2003) Equine melanoma in a population of 296 grey Lipizzaner horses. Equine Vet. J. 35, 153-157

Sica A., Mantovani A. (2012) Macrophage plasticity and polarization: in vivo veritas. J. Clin. Invest. 122, 787-795

Smith S. H., Goldschmidt M. H., Mcmanus P. M. (2002) A comparative review of melanocytic neoplasms. Vet. Pathol. 39, 651-678

Smyth G. B., Duran S., Ravis W., Clark C. R. (1990) Pharmacokinetic studies of cimetidine hydrochloride in adult horses. Equine Vet. J. 22, 48-50

Smyth M. J., Thia K. Y. T., Street S. E. A., Cretney E., Trapani J. A., Taniguchi M., Kawano T., Pelikan S. B., Crowe N. Y., Godfrey D. I. (2000) Differential tumor surveillance by natural killer (NK) and NKT cells. J. Exp. Med. 191, 661-668

Speiser D. E., Pittet M. J., Rimoldi D., Guillaume P., Luescher I. F., Lienard D., Lejeune F., Cerottini J. C., Romero P. (2003) Evaluation of melanoma vaccines with molecularly defined antigens by ex vivo monitoring of tumor-specific T cells. Semin. Cancer Biol. 13, 461-472

Spurrell E. L., Lockley M. (2014) Adaptive immunity in cancer immunology and therapeutics. Ecancermedicalsci. 8, 441

Srinivasan R., Wolchok J. D. (2004) Tumor antigens for cancer immunotherapy: therapeutic potential of xenogeneic DNA vaccines. J. Transl. Med. 2, 12

Sundberg J. P., Burnstein T., Page E. H., Kirkham W. W., Robinson F. R. (1977) Neoplasms of Equidae. J. Am. Vet. Med. Assoc. 170, $150-152$

Sundstrom E., Komisarczuk A. Z., Jiang L., Golovko A., Navratilova P., Rinkwitz S., Becker T. S., Andersson L. (2012) Identification of a melanocyte-specific, microphthalmia-associated transcription factor-dependent regulatory element in the intronic duplication causing hair greying and melanoma in horses. Pigment Cell Melanoma Res. 25, 28-36

Swann J. B., Hayakawa Y., Zerafa N., Sheehan K. C. F., Scott B., Schreiber R. D., Hertzog P., Smyth M. J. (2007) Type I IFN contributes to NK cell homeostasis, activation, and antitumor function. J. Immunol. 178, 7540-7549

Tarhini A. A., Leng S., Moschos S. J., Yin Y., Sander C., Lin Y., Gooding W. E., Kirkwood J. M. (2012) Safety and immunogenicity of vaccination with MART-1 (26-35, 27L), gp 100 (209-217, 210M), and tyrosinase $(368-376,370 D)$ in adjuvant with PF-3512676 and GM-CSF in metastatic melanoma. Immunother. 35, 359-366

Taylor R. C., Patel A., Panageas K. S., Busam K. J., Brady M. S. (2007) Tumor-infiltrating lymphocytes predict sentinel lymph node positivity in patients with cutaneous melanoma. J. Clin. Oncol. 25, 869-875

Terabe M., Berzofsky J. A. (2008). The Role of NKT Cells in Tumor Immunity. Advances in Cancer Research, Vol 101. G. F. VandeWoude and G. Klein. San Diego, Elsevier Academic Press Inc. 101,277

Terabe M., Matsui S., Noben-Trauth N., Chen H. J., Watson C., Donaldson D. D., Carbone D. P., Paul W. E., Berzofsky J. A. (2000) NKT cell-mediated repression of tumor immunosurveillance by IL13 and the IL-4R-STAT6 pathway. Nat. Immunol. 1, 515-520

Tokuyama H., Hagi T., Mattarollo S. R., Morley J., Wang Q., Fai-So H., Moriyasu F., Nieda M., Nicol A. J. (2008) V gamma 9V delta $2 \mathrm{~T}$ cell cytotoxicity against tumor cells is enhanced by monoclonal antibody drugs - Rituximab and trastuzumab. Int. J. Cancer 122, 2526-2534
Topalian S. L., Hodi F. S., Brahmer J. R., Gettinger S. N., Smith D. C., Mcdermott D. F., Powderly J. D., Carvajal R. D., Sosman J. A., Atkins M. B., Leming P. D., Spigel D. R., Antonia S. J., Horn L., Drake C. G., Pardoll D. M., Chen L., Sharfman W. H., Anders R. A., Taube J. M., Mcmiller T. L., Xu H., Korman A. J., Jure-Kunkel M., Agrawal S., Mcdonald D., Kollia G. D., Gupta A., Wigginton J. M., Sznol M. (2012) Safety, Activity, and Immune Correlates of Anti-PD-1 Antibody in Cancer. N. Engl. J. Med. 366, 2443-2454

Topalian S. L., Solomon D., Rosenberg S. A. (1989) Tumor-specific cytolysis by lymphocytes infiltrating human melanomas. J. Immunol. 142, 3714-3725

Tuthill R. J., Clark W. H., Jr., Levene A. (1982) Pilar neurocristic hamartoma: its relationship to blue nevus and equine melanotic disease. Arch. Dermatol. 118, 592-596

Tuting T. (2013) T cell immunotherapy for melanoma from bedside to bench to barn and back: how conceptual advances in experimental mouse models can be translated into clinical benefit for patients. Pigment Cell Melanoma Res. 26, 441-456

U'ren L., Guth A., Kamstock D., Dow S. (2010) Type I interferons inhibit the generation of tumor-associated macrophages. Cancer Immunol. Immunother. 59, 587-598

Ucar K. (1991) The Effects of Histamine-H2-Receptor Antagonists on Melanogenesis and Cellular Proliferation in Melanoma-Cells in Culture. Biochem. Biophys. Res. Commun. 177, 545-550

Valentine B. A. (1995) Equine melanocytic tumors: a retrospective study of 53 horses (1988 to 1991). J. Vet. Intern. Med. 9, 291-297

Wagner S. N., Schultewolter T., Wagner C., Briedigkeit L., Becker J. C., Kwasnicka H. M., Goos M. (1998) Immune response against human primary malignant melanoma: a distinct cytokine mRNA profile associated with spontaneous regression. Lab. Invest. 78, $541-550$

Waldhaver I., Steinle A. (2008) NK cells and cancer immunosurveillance. Oncogene 27, 5932-5943

Wang R. F., Robbins P. F., Kawakami Y., Kang X. Q., Rosenberg S. A. (1995) Identification of a gene encoding A melanoma tumor-antigene recognized by HLA-A31-restricted tumor-infiltrating lymphocytes. J. Exp. Med. 181, 799-804

Weber L. W., Bowne W. B., Wolchok J. D., Srinivasan R., Qin J., Moroi Y., Clynes R., Song P., Lewis J. J., Houghton A. N. (1998) Tumor immunity and autoimmunity induced by immunization with homologous DNA. J. Clin. Invest. 102, 1258-1264

Weide B., Garbe C., Rammensee H.-G., Pascolo S. (2008) Plasmid DNA- and messenger RNA-based anti-cancer vaccination. Immunol. Lett. 115, 33-42

Wolchok J. D., Kluger H., Callahan M. K., Postow M. A., Rizvi N. A., Lesokhin A. M., Segal N. H., Ariyan C. E., Gordon R. A., Reed K., Burke M. M., Caldwell A., Kronenberg S. A., Agunwamba B. U., Zhang X., Lowy I., Inzunza H. D., Feely W., Horak C. E., Hong Q., Korman A. J., Wigginton J. M., Gupta A., Sznol M. (2013) Nivolumab plus ipilimumab in advanced melanoma. N. Engl. J. Med. 369, 122-133

Wolchok J. D., Yuan J., Houghton A. N., Gallardo H. F., Rasalan T. S., Wang J., Zhang Y., Ranganathan R., Chapman P. B., Krown S. E., Livingston P. O., Heywood M., Riviere I., Panageas K. S., Terzulli S. L., Perales M. A. (2007) Safety and immunogenicity of tyrosinase DNA vaccines in patients with melanoma. Molecular therapy. 15, 2044-2050

Woo S. R., Corrales L., Gajewski T. F. (2015) Innate immune recognition of cancer. Ann. Rev. Immunol. 33, 445-474

Woo S. R., Fuertes M. B., Corrales L., Spranger S., Furdyna M. J., Leung M. Y. K., Duggan R., Wang Y., Barber G. N., Fitzgerald K. A., Alegre M. L., Gajewski T. F. (2014) STING-Dependent Cytosolic DNA Sensing Mediates Innate Immune Recognition of Immunogenic Tumors. Immunity 41, 830-842

Wood S. R., Berwick M., Ley R. D., Walter R. B., Setlow R. B., Timmins G. S. (2006) UV causation of melanoma in Xiphophorus is dominated by melanin photosensitized oxidant production. Proc. . Nat. Acad. Sci. U. S. Am. 103, 4111-4115

Wu D. Y., Segal N. H., Sidobre S., Kronenberg M., Chapman P. B. (2003) Cross-presentation of disialoganglioside GD3 to natural killer T cells. J. Exp. Med. 198, 173-181 
Wu Y., Wu W., Wong W. M., Ward E., Thrasher A. J., Goldblatt D., Osman M., Digard P., Canaday D. H., Gustafsson K. (2009) Human gamma delta T Cells: A Lymphoid Lineage Cell Capable of Professional Phagocytosis. J. Immunol. 183, 5622-5629

Wu Y. L., Liang J., Zhang W., Tanaka Y., Sugiyama H. (2012) Immunotherapies: the blockade of inhibitory signals. Inte. J. Biol. Sci. 8, $1420-1430$

Yaddanapudi K., Putty K., Rendon B. E., Lamont G. J., Faughn J. D., Satoskar A., Lasnik A., Eaton J. W., Mitchell R. A. (2013) Control of tumor-associated macrophage alternative activation by macrophage migration inhibitory factor. J. Immunol. 190, 2984-2993

Yamaguchi Y., Hearing V. J. (2009) Physiological factors that regulate skin pigmentation. Biofactors 35, 193-199

Yang X., Du J., Xu X., Xu C., Song W. (2014) IFN- -Secreting-Mesenchymal Stem Cells Exert an Antitumor Effect In Vivo via the TRAIL Pathway. Immunol. Res. 2014, 318098

Yuan J., Ku G. Y., Gallardo H. F., Orlandi F., Manukian G., Rasalan T. S., Xu Y., Li H., Vyas S., Mu Z., Chapman P. B., Krown S. E., Panageas K., Terzulli S. L., Old L. J., Houghton A. N., Wolchok J. D. (2009) Safety and immunogenicity of a human and mouse gp 100 DNA vaccine in a phase I trial of patients with melanoma. Cancer Immun. 9, 5

Zabuawala T., Taffany D. A., Sharma S. M., Merchant A., Adair B., Srinivasan R., Rosol T. J., Fernandez S., Huang K., Leone G., Ostrowski M. C. (2010) An Ets2-Driven Transcriptional Program in Tumor-Associated Macrophages Promotes Tumor Metastasis. Cancer Res. 70, 1323-1333

Zhang Q. W., Liu L., Gong C. Y., Shi H. S., Zeng Y. H., Wang X. Z., Zhao Y. W., Wei Y. W. (2012) Prognostic significance of tumorassociated macrophages in solid tumor: A meta-analysis of the literature. PLoS One 7, 14

Zhou W. Z., Kaneda Y., Huang S., Morishita R., Hoon D. (1999) Protective immunization against melanoma by gp100 DNA-HVJ-liposome vaccine. Gene Ther. 6, 1768-177

Erweiterte Zusammenfassung

\section{Perspektiven für immunologische Therapien des Malignen Melanoms beim Pferd}

Melanome sind bei Pferden, in den meisten Fällen bei Schimmeln, häufig auftretende Neoplasien der Haut. Typischerweise sind ältere vergravende Pferde betroffen, die kutane Tumoren der pigmentbildenden Zellen an Prädilektionsstellen wie der Unterseite der Schweifrübe, der Perianalregion, dem Präputium, Augenlidern, Lippen oder der Parotis zeigen. Nach einem initial meist langsamen invasiven Wachstum kommt es häufig in einem späteren Stadium zur Tumormetastasierung. Eine genetische Komponente der Melanomentstehung wurde durch den Zusammenhang des autosomal dominanten Merkmals mit dem Alter zu Vergrauen und der Entstehung von Melanomen gefunden. Aufgrund der immunhistochemischen und histomorphologischen Vergleichbarkeit des equinen Melanoms mit bestimmten Typen des humanen Melanoms scheinen an Melanomen erkrankte Schimmel geeignet als Modelltiere für bestimmte humane dermale melanozytäre Erkrankungen wie maligne blave Nevi und desmoplastische Melanome. Aufgrund der Entstehung aus körpereigenen Zellen, ist die Bekämpfung von Neoplasien eine Herausforderung für das Immunsystem.
Trotz Infiltration solider Tumoren mit verschiedensten Immuneffektorzellen sind diese häufig nicht in der Lage, eine bedeutsame Tumorregression zu bewirken. Die T-Zellinfiltration in soliden Tumoren beinhaltet häufig regulatorische Zellen und Substanzen, die eine effektive Tumorlyse verhindern. Zur effektiven Tumorbekämpfung ist das konzertierte Zusammenspiel des angeborenen (unspezifischen) mit dem adaptiven (spezifischen) Immunsystem unabdingbar. An der Erkennung und Abwehr von Tumoren sind Antigen-präsentierende Zellen, neutrophile Granulozyten und lymphoide Zellen der unspezifischen Immunabwehr beteiligt. Eine Polarisierung dieser Zellen zugunsten einer antitumoralen Wirksamkeit (Makrophagen vom Typ I, neutrophile Granulozyten vom Typ I, T-Helfer-Zellen vom Typ I) führt zu Synergien in der Tumorabwehr. Interferone spielen hierbei eine Rolle in der Aktivierung und Stimulation der Effektorzellen. Unspezifische lymphoide Zellen sind durch ihre Fähigkeit zur frühen Antwort auf Entzündungsprozesse wichtige Zelltypen in der frühzeitigen Erkennung entarteter Zellen. In der spezifischen Tumorimmunität spielen tumorassoziierte Antikörper (TAA) eine zentrale Rolle in der Antitumorantwort. Verschiedene TAA des Melanoms sind bekannt und können als Ziel einer Immuntherapie fungieren. Sie werden den T-Zellen entweder durch antigen-präsentierende Zellen oder durch MHC-Komplexe dargeboten. Nach Erkennung der TAA durch T-Zellen können dann weitere Effektorzellen aktiviert, Chemokine und Zyłokine freigesetz† und co-stimulatorische Moleküle induziert werden. Dadurch wird dann eine eher zelluläre Th 1 Antwort oder eine vornehmlich humorale Th2-Antwort stimuliert. Damit die Immunantwort koordiniert abläuft und der unspezifischen Reaktion eine antigenspezifische Antwort folgt, müssen die beiden Anteile des Immunsystems gut vernetzł sein. Interferone übernehmen wichtige Aufgaben in dieser Vernetzung der antitumoren Immunantwort. Auch TumorDNA kann im Zytosol dendritischer Zellen erkannt werden und damit zur Aktivierung der unspezifischen Abwehrmechanismen beitragen. Daher und aufgrund des guten Ansprechens Melanome anderer Spezies auf eine immunmediierende Therapie ist die Immuntherapie von equinen Melanomen eine vielversprechende Forschungsrichtung. Es gibt Untersuchungen zur Immuntherapie des equinen malignen Melanoms mit antitumoral wirkenden Zytokinen aber auch mit Tumorvakzinen. Die Mehrzahl der untersuchten therapeutischen Strategien zeigte in klinischen Studien auf partielle Tumorregression begrenzte Erfolge. Eine der erfolgversprechendsten Therapien scheint die Vakzinierung von Melanompatienten mit xenogener (humaner) Tyrosinase-DNA zu sein. Bisher fehlen allerdings noch wissenschafltich publizierte Daten zum klinischen Therapieerfolg der Vakzine. Zukünftig könnten auch beim Pferd Therapieansätze mit mehr als einem Zielmolekül/einer Zielzelle in den Fokus der Melanomtherapieforschung rücken. Solche kombinierten Therapien sind vermutlich effektiver als Monotherapien und könnten beispielsweise auch die Kombination lokaler Chemotherapie zur Tumordestruktion und Freisetzung von Tumorantigenen mit immunstimulatorischen Substanzen zur effektiven Erkennung der freigesetzten TAA einschließen. Der Fokus dieses Übersichtsartikels liegt auf den Möglichkeiten der Immuntherapie equine maligner Melanome und ihrer potenziellen zukünftigen Anwendung am Patienten. 